\title{
Statistics To Plan: Statistical Development in a Regional System of Public Libraries (Valencian Community - Spain)
}

\author{
Ignacio Latorre Zacarés
}

Head of the Department of Libraries.

Department of Books and Libraries of the

Valencian Autonomous Government (Valencian Community - Spain)

latorre_ign@gva.es. Conselleria de Cultura, Educación y Deporte.

Dirección General del Libro y Bibliotecas. Servicio del Libro.

Avenida Campanar, 32.

46015 Valencia (Spain)

\section{Milagros Ortells Montón}

\section{Library Technician.}

Department of Books and Libraries

of the Valencian Autonomous Government

(Valencian Community - Spain)

ortells_mil@gva.es.

Conselleria de Cultura, Educación y Deporte.

Dirección General del Libro y Bibliotecas.

Servicio del Libro. Avenida Campanar, 32.

46015 Valencia (Spain)

For the Department of Books and Libraries of the Valencian Autonomous Government, the year 2000 was the starting point of a new strategy of library policy ${ }^{1}$, that incorporated, inter alia, the following objectives: a reliable knowledge of the public library system of the Valencian Community, the establishment of a regional library electronic network, the approval of new grants for the public libraries, the legal adaptation of the library system and the creation of new aid instruments for the libraries and its professional staff (on-line bibliographies, Web page at regional level and Portal of Valencian Libraries, distribution list of information, databases of the Valencian Library System, etc.). The entire programme begun with the preparation of the Map of Public Reading of the Valencian Community and the improvement of the statistical system of the Valencian Library System which has allowed having a better knowledge of the 
current state of the regional library network and that acts as a tool for the making of decisions in library policy. This paper analyzes the progress made in statistical management and its practical applications in the adoption of planning strategies and in research on public libraries.

\section{Valencian Library System}

The Valencian Community is a Spanish autonomy with capital in the city of Valencia. Valencia has 4.600.000 inhabitants and 542 towns integrated in 3 provinces (Alicante, Castellón and Valencia). Although the Valencian Library System was created in 1987 by the law 10/1986 relating to the Library Organization of the Valencian Community http://www.cult.gva.es/dglb/bibliotecas-f_e.htm (inscription of Valencian Library legislation), its beginnings go back to 1983, when the Spanish Central Government transfers the powers regarding libraries to the Valencian Autonomous Community, within the framework of political and administrative decentralisation made possible by the Spanish Constitution of 1978. Since then, the Valencian Library System has been characterized by a policy of establishing libraries in many towns that lacked a public library service, as well as the extension of the urban library networks in large and medium-sized towns. By 31 December 2004, there were 532 centres of public reading in the Valencian Community including provincial public libraries, municipal public libraries, branch libraries, etc. 98'3\% of the Valencian population live in towns that have public library service and all the towns of more than 3.000 inhabitants (except one) have public library. $98 \%$ of the public libraries belong to the local administration.

\section{Reasons for an improvement of the statistical system}

Despite the rapid expansion of the public library system throughout the Valencian Community, there are certain deficiencies that adversely affected (and still do) the Valencian libraries: chronic lack of suitable budgets, lack of professionals in the libraries of small towns, small size of many of the libraries, lack of renewal of the bibliographical resources, reduced timetable for attending the public in small towns, lack of library service in the towns with less demography, limited presence of mobile libraries, lack of computerisation in an important number of libraries, lack of legal adjustment of the system to the new conditions and functions of the libraries in the Information Society, etc.

The autonomous institution of library policy was partially aware of the deficiencies of the library system, but the extent of the problems and shortcomings as well as their geographic distribution were not exactly known. The need to create instruments that could help in the understanding of the real situation of libraries in order to draw up a corresponding policy was soon evident. 
One of the first measures for obtaining an accurate knowledge of the situation was the Map of Valencian Public Reading ${ }^{2}$ drawn up between year 2000 and 2001. This Map analyzed all the parameters of use, services, facilities, personnel and expenditure that affected the Valencian public libraries through on-the-spot surveys in each of the libraries. The Map of Valencian Public Reading meant the creation of a powerful database that also provided an improvement in the whole statistical system of the Valencian Community that since its creation it was simply limited to the monthly compilation of certain data: visitors, loans, registred users and total number of resources. In addition, the Library Inspection Service was set up in November 2000 as an instrument of control and knowledge of the library system.

The Map of Valencian Public Reading confirmed the absence of computerisation in many libraries. Thus, the first measure that to be implemented, thanks to a better knowledge of the state of affairs in libraries, was the creation of the Valencian Public Reading Electronic Network ${ }^{3}$ on 18 September 2001 which currently integrates 223 libraries (http://xl p v.cult.gva.es/). The second measure was the change of orientation in the grant policy for the purchase of basic library resources, giving priority to the purchases for diversification of the bibliographical supply (fiction, juvenile literature, essay...) rather than to a subsidized purchase that was previously very much directed towards reference works (encyclopedias), particularly in small towns.

The current situation of libraries unveiled the need of a progressive improvement in the entire statistical system. From the very beginning, it was also decided that the whole statistical process (dispatch of questionnaires, creation of tools, tabbing and use of data, verification of data, supply of statistical information) should be kept in the hands of the officials of the Department of the Books and Libraries, without outsourcing it, so that our Department was in control of the full process.

\section{Creation of XABIB: database of the Valencian Library System}

All the changes projected to improve the Valencian statistical system made necessary the creation of a powerful database that centralised all the quantitative -and sometimes qualitative- information, of the Valencian libraries. In this context and thanks to the collaboration between the librarians and computer technicians ${ }^{4}$, the database $\mathrm{XABIB}^{5}$, was set up in the year 2000. XABIB becomes the central and "hard" core of all the subsequent computer developments related to library statistics.

XABIB is a database developed in Database Oracle9i that has the PowerBuilder Release 7 as the development tool for the application. It is an application clientserver in which the users of maintenance and processing have typical Windows 98 
and Windows 2000 posts integrated in a network managed by Windows 2000 . Furthermore, the database is connected through common tables with other databases of the Culture Department of the Valencian Government. It is perhaps a somewhat complex tool for the data entry, but it is very powerful with respect to the large storage capacity of information and the enormous possibilities about data processing and development of Web applications.

XABIB adopts a tree structure, organized in displayable menus under the following sections:

- Maintenance: it contains the directory of libraries that includes data on location: address, telephone, fax, e-mail, person responsible, Web page ...

- Observations: it stores qualitative information entered by the Library Inspection Service.

- Annual data: it includes all the data yearly requested by the institutions of the Department of Culture, Education and Sport, such as the Culture Ministry, the National Statistical Institute and the Valencian Statistical Institute. It also includes all the parameters that can be of interest for the Department of the Books and Libraries. These data are the ones referring to personnel, collection, loans, movements, users, registred users, activities, expenditure, timetables, automatization, Internet service, services and facilities, documentary products, periodic publications ...

- Monthly data: it collects the data provided by the historical series of monthly statistics on visitors and loans according to language. In a second option, the data on loans of special material are introduced (periodic publications, voice, audiovisual and electronic documents).

- Lists: it is an option that permits the standardized printing of labels and lists with the synthesized addresses of the libraries (code, name, town or city).

- Local aid: it gathers information on all the grants and aid that the autonomous government has granted since 1984 to the city councils for the maintenance of their libraries.

The statistical applications mentioned in this paper will come out from this central core. In addition to the computer copies, there is also a paper file of the annual and monthly statistics that are archived with the corresponding name and area of the library following a chronological and alphabetical order. These folders are kept in boxes that are passed on to the management records and afterwards to the intermediate archives. 


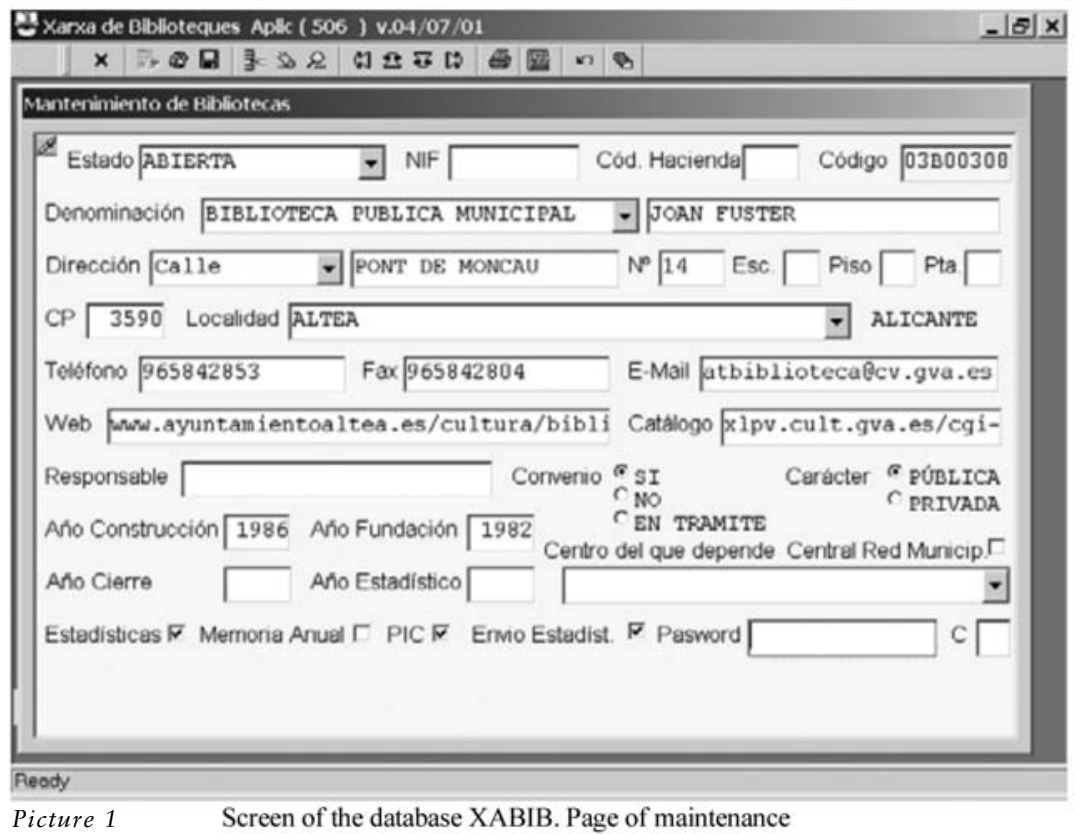

\section{Update and check of the directory of Valencian libraries}

Once the database XABIB was created, subsequent efforts were focused on the update of the directory of all the Valencian libraries: public libraries, university libraries, specialized libraries, private libraries, documentation centres, libraries in hospitals and prisons, etc. This update and check of data was made through on-the-spot surveys of the Map of Valencian Public Reading as well as by telephone contacts with all the city councils. The result of these efforts was the disclosure of an unknown number of libraries as well as the information about libraries that were closed. The directory of Valencian libraries continues being updated on a daily basis and on-line and, furthermore, every year, a copy of the existing data of the directory of each library (address, e-mail, telephone, Web, library) is sent for its check and correction by the libraries integrated in the directory. When the annual questionnaire is sent, the responsible of the libraries are informed that they should communicate any change produced over the year in its directory to the Department of the Books and Libraries. When new data are introduced, priority is given to data entailing a change in the directory, because this information can be 
consulted on-line via Web, and the citizen should receive the most reliable and updated information.

\section{Integration of information into the Spanish statistical system of public libraries}

In 2001, in parallel with the process of improvement in statistical management, the Valencian Community joined the Group of Statistics of Public Libraries. This group has a national dimension and was created in 19976, thanks to the cooperation between the Spanish Ministry of Culture and the institutions in charge of library policies of the different Spanish regions. The group has worked satisfactorily and has secured, in the short term, reliable statistics of the whole Spanish public library system based, firstly, on the Regulation ISO 2789:1991 and, currently, on ISO 2789:2003. This Working Group has managed to have an annual picture of the state of the public library system in Spain that allows the comparative study at a national and international level. At present, the Valencian Library System provides its statistical data of the province and of the Autonomous Community to the Spanish Group of Statistics of Public Libraries and collaborates in the design of questionnaires and the completion of new aims (preparation of indicators, etc.).

\section{Update of statistical questionnaires: monthly statistics and the annual questionnaire}

The Valencian Community collects a historical series of monthly statistics based on data related to visitors, loans, registred users and total number of books and documents of the Valencian public libraries. In 2001, the questionnaire of monthly statistics was updated in order to enable the inclusion of the loans of special material as well as the loans in foreign languages. Furthermore, certain monthly data were no longer requested, as they were already collected in the annual statistical questionnaire. Therefore, these statistics now reflect only the monthly movement of visitors and loans.

However, monthly statistics did not provide an overall picture of the Valencian Library System since there were great many issues that were not addressed: personnel, expenditure, services, facilities, etc. It was necessary to further increase the knowledge of the real situation of the Valencian libraries. Hence, in 2001 a new type of annual survey addressed at the public libraries was drawn up. This new annual survey collects all the parameters applicable to libraries in order to carry out a more rigorous statistical analysis of the Valencian Library System. At the beginning, the survey was only intended for the public libraries, but it was also applied to another type of libraries (specialised, private, libraries in hospitals and prisons...). At present, it is only sent to public libraries. 
This annual survey was used for the first time in the collection of data of the year 2000 and is elaborated in a way that enables the delivery of statistical data requested by the Ministry of Culture, the National Statistical Institute and the Valencian Statistical Institute, as well as parameters of interest for the Department of Books and Libraries of the Valencian Autonomous Government. The survey is reviewed annually according to criteria adopted by the Spanish Working Group of Statistics of Public Libraries in compliance with the Regulation ISO 2789:2003. Therefore, from the first survey elaborated in the year 2000 until the present time, changes have been made with the intention of standardising and controlling the most significant parameters at library level.

\section{Simplification of the sending procedure of statistics}

In order to increase the collaboration of the Valencian libraries in the execution and sending of statistics, there was an attempt to simplify the process of the sending of monthly statistics. Until 2001, the delivery of the historical series of monthly statistics was made only by postal mail. From 2001, new electronic models of statistics were made and the sending of statistics via electronic mail was also permitted. In 2002 a new model to send monthly statistics was established, based on the introduction of the monthly statistics in XABIB directly by the libraries, via the Internet. It is the fastest and simplest way of data transmission for the libraries. Those responsible for the libraries go to the page of the Library section of the Department of the Book and Libraries http://www.cult.gva.es/dglb/bibliotecasf_e.htm (item: "monthly Statistics") and using the code of the centre and the access key, can introduce the statistical data and keep a printed copy.

In the case of the annual surveys and due to the complexity in data entry, the dispatch of statistics is only made through postal or electronic mail. It is not possible for the librarian to introduce the data directly in XABIB. The data coming from annual statistics are directly introduced by the personnel of the Department of Books and Libraries.

\section{Improvements in the consistency of data: process of filtering and checking of data} One of the most difficult tasks at a statistical level is obtaining the greatest level of consistency and coherence in the data. In the case of monthly statistics, the simplicity of the requested data and the historical nature of the series has made it possible to achieve a considerable level of consistency of the data. The time factor is often one of the best recipes for obtaining a greater coherence in the supply of information, because professionals are improving the ways of compiling and providing the information required. However, monthly statistics are also subject to a data filtering process before their final entry in XABIB, even in cases where statistics are introduced by librarians. 
As explained before, the series of annual statistics are more recent (data exist since the year 2000) and comprises a greater amount and complexity of parameters. Thus, in this type of statistics, since 2001 (when the registration of this type of data began), a special effort of filtering and checking of data has been undertaken. Efforts have been made to rectify all the possible errors and the lack of data by many telephone calls or via fax, postal or electronic mail. In this context, time has also been an important ally and, over the years, a clear improvement in the coherence and the volume of the data provided by the libraries has been perceived. On the other hand, efforts have been made to make the questionnaire as clear as possible. The experience of each year and the identification of recurring errors when analisyng out statistics have resulted in the inclusion of new explanatory notes or "aids" in the questionnaire, in order to guide the librarians and secure a greater reliability in the statistical data. The current policy consists in amending the questionnaire as little as possible and in continuing to offer better consistency levels.

\section{Creation of the on-line Directory of Valencian Libraries}

The Department of Books and Libraries has always considered that the computer tools created for the internal management of the work might have a Web application which allowed part of the work to be published openly. Thus, in 2002 the Web version of XABIB was created as well as the external database of the Valencian Library System. This Web application allows the open, versatile and online consultation of the principal data of the Valencian Library System through the Web http://www.cult.gva.es/dglb/bibliotecas-f_e.htm (inscription XABIB). The database allows researching information according to typology of libraries, town, region, provinces, number of inhabitants, etc. The result is a list of libraries that answers to the search criteria used, with its basic data of the directory: name, library typology, postal address, electronic address, telephone, etc. By clicking in each reference, one has access to an index card of the library centre with the timetable of the library and to another index card with the services and facilities of the library. The users of this application may also obtain labels with a standardized format with the addresses of the Valencian libraries. They can also enter the Web pages of the selected libraries as well as their catalogues. This Web application of XABIB is also integrated in the interface of the Electronic Network of Valencian Public Reading (http://xlpv.cult.gva.es/), which is connected with any catalogue of the libraries within the network. In this way, when a specific book in the catalogue of one of the libraries is found, one can also consult the address, the electronic mail or the timetable of the chosen library. 


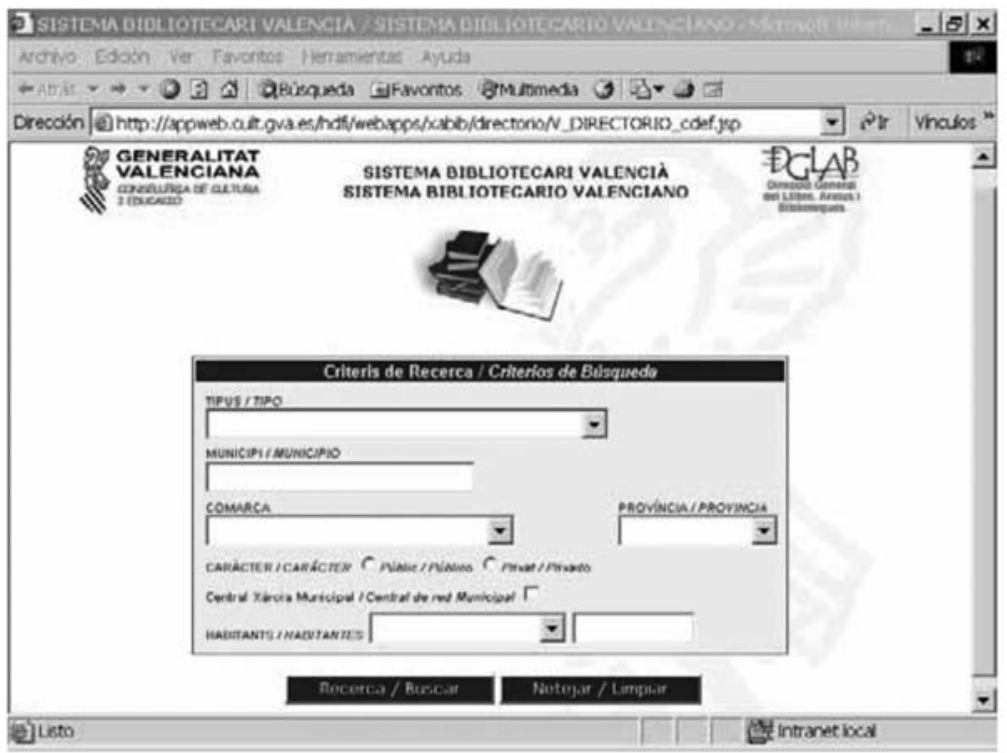

Picture 2

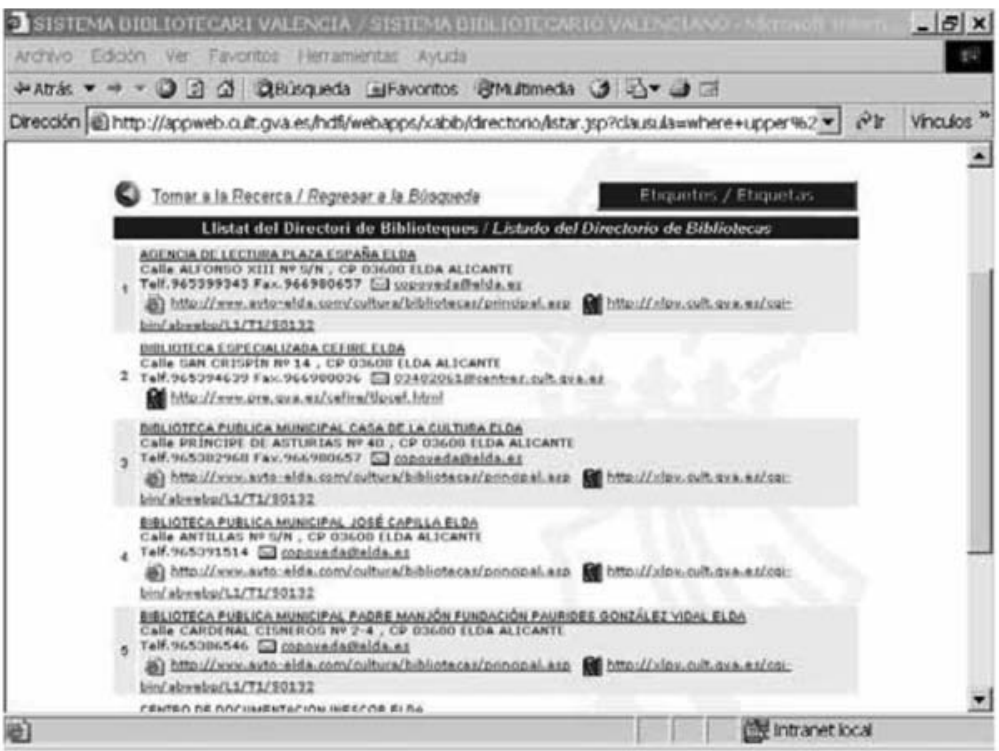

Picture 3. Screens of free access web pages of the Valencian Library Directory (XABIB). 


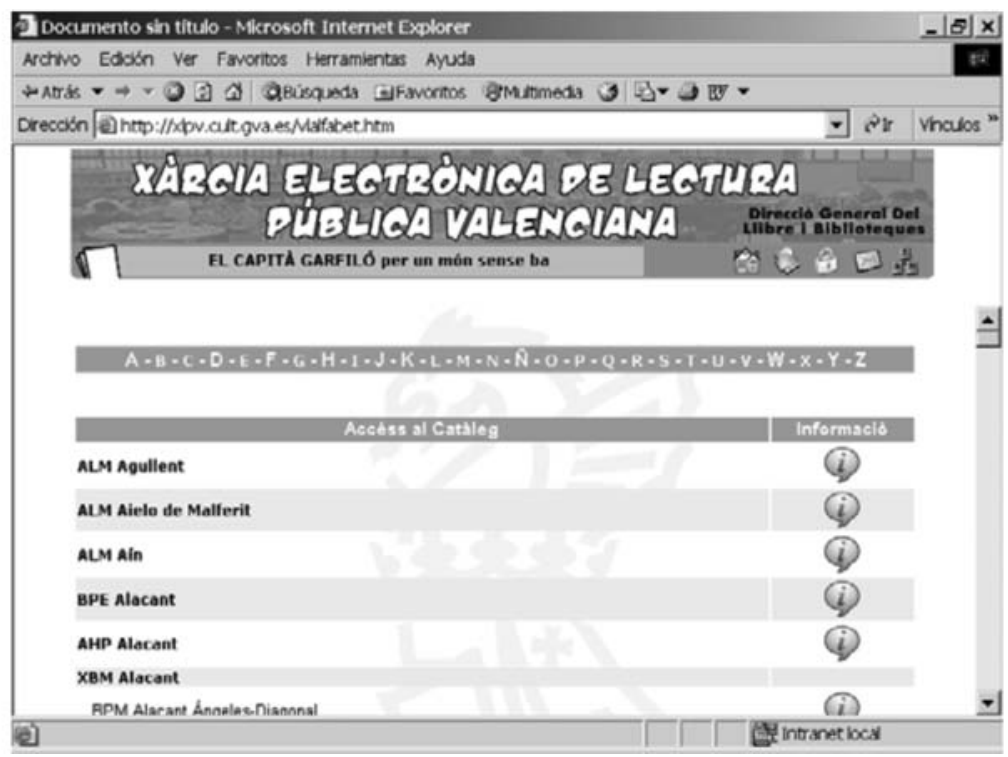

Picture 4. XАВIB web application is also integrated in the interface of the Electronic Network of Valencian Public. Reding connecting catalogues with data of the libraries directory.

\section{Programme for obtaining statistical information of internal use}

A programme for obtaining statistical information for the development of data stored in XABIB was set up. It was based on an already existing tool developed by the Valencian Government of design of forms in Internet called the HDFI. It is a very complete programme and with full possibilities of development since it extracts the information in Excel format from very open consultations of the data introduced in XABIB. The interface divides the consultation of data into 21 sections: library centres, users, loans, registred users, inter-library loan, library surface, timetables, periodic publications, activities, automatisation, Internet and Web, collection, bibliographical movement, services, facilities, expenditure, staff, documentary products, aid to towns, mobile and temporary libraries along with monthly statistics. All these sections can be restricted by year, by geographic distribution (provinces, county, towns), by demographic magnitude and other criteria. Getting the information in Excel tables permits huge versatility in working with the statistical information and makes the supply of the data requested by the different institutions very easy. This programme is for the internal use of the department. 


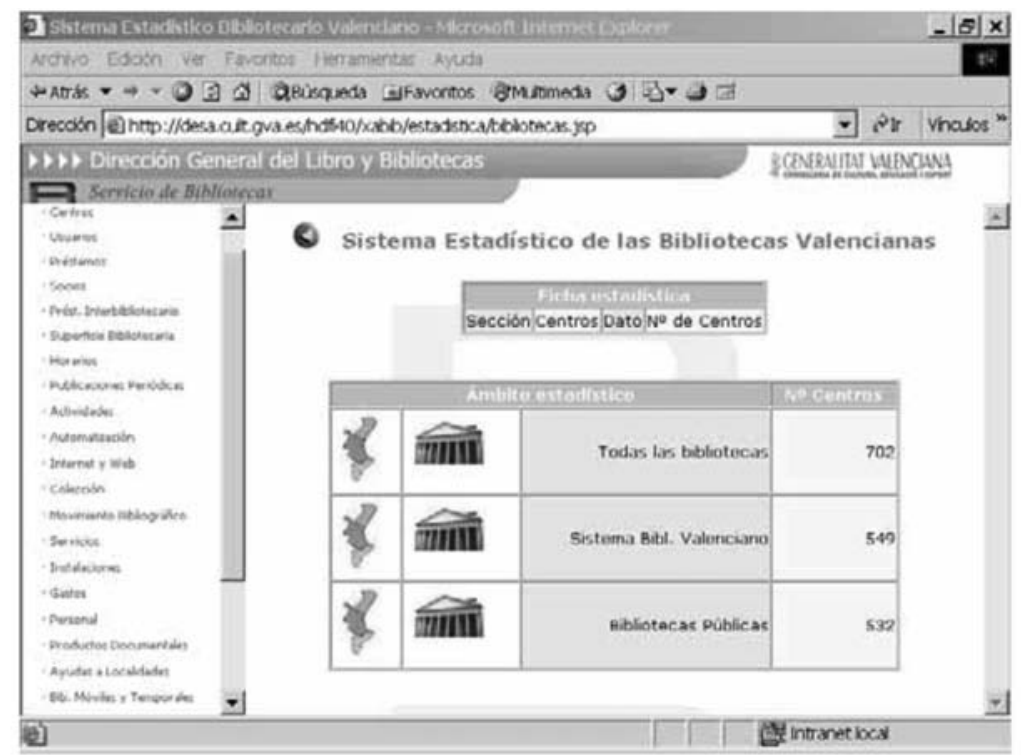

Picture 5. Online statistical data search screen in the Dynamic Map of Libraries. To the left, search criteria: Centers, users, loans, members, activities, expenditure, personnel, database, etc.

\section{5: The Dynamic Map of Valencian Libraries}

In the same way as was done with the directory of Valencian libraries (XABIB), the Department of Books and Libraries has also been working in order to have an open and web version of the programme. Therefore, in June 2005 the Dynamic Map of Valencian Libraries on the Web was created on the following page: http://www.cult.gva.es/dglb/bibliotecas-f_e.htm (inscription "Mapa Dinámico de Bibliotecas Valencianas"). The Dynamic Map of Valencian Libraries is the Web version of the internal programme for obtaining data, but with greater possibilities for making diagrams and very intuitive consultations aimed at the citizen. The level of consultation goes down to the town level and it is possible to carry out historical consultations with graphic information. The sections that can be publically consulted are very similar to the sections of the internal system of utilization of data and the parameters in open exceed 200. The Dynamic Map is also based on HDFI (Tool of Design of Forms in Internet) and it has a specific package of Java to generate graphics. The work of all the professionals interested in this subject -librarians, students, researchers, means of communication, etc.- is facilitated by this tool. 


\section{Practical applications of statistical management and approaches for the future}

The investment in statistical management quickly brought good results regarding data supply. The whole process of improvement has permitted, in a relatively easy way, all provision of the data annually requested by the Spanish Ministry of Culture, the National Statistical Institute and the Valencian Statistical Institute. These statistical tools serve very often to answer certain specific reports requested by the Valencian Government or by its Department of Culture, as well as those requested by other departments. The data are analyzed by the Department of Books and Libraries for making reports on this subject and, occasionally, serving as a basis for the adoption of measures of improvement. Furthermore, some of these reports have been published ${ }^{7}$ in specialised magazines. In other instances, the annual overall statistical information has been provided to the media, so that citizens may appreciate the importance and the dynamism that public libraries have in present society. Working with the data has also allowed the drawing up of articles on certain aspects of the Valencian Library System ${ }^{8}$, and we expect that with the new Web application (Dynamic Map of Libraries), research in this field will increase.

On the other hand, since 2004, the Department of Books and Libraries, via its statistical programme, has also collaborated in the "Project Tibidabo" (http://www.tibidabo-libraries.info/), programme of the Diputació de Barcelona and the Consorci de Biblioteques de Barcelona carried out with the Foundation Germán Sánchez Ruipérez. This project concerns a comparative study between 2000 and 2003 of the situation and evolution of the public library service in cities and regions of Europe: Valencia, Barcelona, Madrid, Zaragoza, Oslo, Birmingham, Bremen, Helsinki, Stuttgart and Dublin.

The data are the principal part of statistical management, but these data only register facts without providing any value or interpretative judgment. The data must be analyzed, valued, and interpreted in order to generate information and, at the same time, knowledge. The information and the knowledge generated allow us to have a clear vision of the real situation of libraries and, at the same time, this knowledge allows for consistent policies and strategies to be adopted. The better the information; the greater the capacity to adopt adequate and appropriate decisions. In this context, the crossing of the library data strictly with demographic, economic and sociological variables produce indicators that allow a deeper knowledge of the situation and a greater capacity of comparison with the levels or ratios of other regions. The figures or absolute data must be analyzed and translated into ratios and indicators that allow a better understanding of the situation. The comparisons by chronological periods reflect on the degree of development of the different parameters and the dynamics, more or less positive, in each section (for example, sustainable and significant increase in number of visitors, stagnation in investments, 
improvements in the computer equipment, etc.). Also, the preparation of graphics helps understanding and makes the reality of the situation or its development in a certain number of years more visible: graphics of loans per years, graphics of change in monthly visits, etc. It is very important to be able to study the data by geographic areas, so that one can delimit the indicators by districts, towns, etc. The library situation often changes radically in relation to the region. In short, once the right tools for statistical management exist, it is more and more necessary to further analyze the data and work with them for developing indicators and zonal studies. On the other hand, another essential aim in statistical management is to obtain each time a greater consistency level in the data.

\section{Notes}

1. Coordinating institution of library policy in the Valencian Community (Spain). At that time, Department of the Book, the Archives and the Libraries.

2. GALÁN SERRANO, Noemí; et al. "El mapa de lectura pública valenciana: un instrumento de trabajo y planificación”. En: La biblioteca pública, portal de la sociedad de la información: actas: Primer Congreso Nacional de Bibliotecas Públicas: Valencia...2002. Madrid: Ministerio de Educación, Cultura y Deporte, 2002. P. 383-393. http://travesia.mcu.es/documentos/actas/com_383.pdf

3. LATORRE ZACARÉS, Ignacio; CERDÁ VARA, Francisca. "Programa de Informatización Común de las Bibliotecas Valencianas". Compactus: revista d'arxius i biblioteques. 2001 septiembre-diciembre, n. 2, p. 3-5. http://www.cult.gva.es/dglb/compactus/numero2/article.pdf

CERDÁ VARA, Francisca; LATORRE ZACARÉS, Ignacio. "Trabajo cooperativo en redes electrónicas y catálogos colectivos en línea: la Red de Lectura Pública Valenciana". En: La biblioteca pública, portal de la sociedad de la información: actas: Primer Congreso Nacional de Bibliotecas Públicas: Valencia 2002. Madrid: Ministerio de Educación, Cultura y Deporte, 2002. P. 37-45. http://xlpv.cult.gva.es/files/Artredelec.pdf

CERDÁ VARA, Francisca; LATORRE ZACARÉS, Ignacio. "Catálogo Colectivo de la Red de Lectura Pública Valenciana: logros y problemas tras 21 meses en funcionamiento". En: 1as. Jornadas del Sistema Nacional de Bibliotecas de Euskadi (16-17 octubre 2003). 2003. http://xlpv.cult.gva.es/files/catcolPV.pdf 
4. We thank Rafael Martín and Javier Belmonte, computer technicians, for the technical data of a computer nature provided for the preparation of this communication. We thank also Deborah Hall, Elena Ortells and Ana-Rosa Latorre for their assistance and collaboration.

5. These letters stand for the corresponding expression for "Net of libraries" in the Valencian language.

6. SELGAS GUTIÉRREZ, Joaquín. "Las estadísticas de bibliotecas públicas en España: pasado, presente y perspectivas de futuro". En: La biblioteca pública: un compromiso de futuro: actas: II Congreso Nacional de Bibliotecas Públicas: Salamanca...2004. Madrid: Ministerio de Cultura, 2004. P. 172-182. http://travesia.mcu.es/documentos/congreso_2bp/1a_sesion/comunicacion17.pdf

7. “Bibliotecas valencianas: estadísticas del año 2001”. Compactus: revista d'arxius i biblioteques. 2002 mayo-agosto, n. 4, p. 47-49. http://www.cult.gva.es/DGLB/compactus/numero4/biblionoticies.pdf LATORRE ZACARÉS, Ignacio. "Bibliotecas Públicas Valencianas: estadísticas del año 2002". Compactus: revista d'arxius i biblioteques. 2003 mayo-agosto, n. 7, p. 4-7. http://www.cult.gva.es/DGLB/compactus/numero7/reportatges.pdf

8. ORTELLS, Milagros; SEPÚLVEDA, Gloria y LATORRE, Ignacio. "Bibliotecas públicas en comarcas con elevado índice de ruralidad: el ejemplo de la provincia de Valencia". En: La Biblioteca Pública un compromiso de futuro: actas: II Congreso Nacional de Bibliotecas Públicas: Salamanca...2004. Madrid: Ministerio de Cultura, 2004. P. 82-94. http://travesia.mcu.es/documentos/congreso_2bp/1a_sesion/comunicacion07.pdf

\section{Abstract}

In 2000, the coordinating institution of library policies in the Valencian Community (Spain) began a process of improvement in the statistical system of the Valencian Library System that has allowed a better knowledge of the current state of the regional library network and which acts as a tool for the decisionmaking process in connection with library policies. This paper analyzes the progress brought about in statistical management, the new computer programmes developed and its practical applications in library policies and in research on public libraries. 
Key words: Statistical management/ Data processing/ Library policy/ Computer programmes/ Valencian Library System

Resumen: En el año 2000, el organismo coordinador de política bibliotecaria en la Comunidad Valenciana (España) inició un proceso de mejora de la gestión estadística del Sistema Bibliotecario Valenciano que ha permitido poseer un mejor conocimiento del estado actual de la red bibliotecaria regional y que actúa como herramienta para la toma de decisiones de política bibliotecaria. La comunicación analiza los progresos realizados en la gestión estadística, las nuevas aplicaciones informáticas desarrolladas y sus aplicaciones prácticas en política bibliotecaria y en investigación sobre bibliotecas públicas.

Palabras clave: Gestión Estadística / Procesamiento de datos / Política bibliotecaria / Aplicaciones informáticas / Sistema Bibliotecario Valenciano 